\title{
Corporate Social Responsibility: Organization's Pull And Push Strategy
}

\author{
ABIOLA IDOWU \\ Department of Management and Accounting \\ Ladoke Akintola University of Technology, Ogbomoso. \\ Oyo State, Nigeria.
}

\begin{abstract}
Corporate Social Responsibility, though not a new concept to both foreign and indigenous organizations operating within the shore of Nigeria and as well as researchers in the management field, however, the strategy been utilized is not gaining required recognition hence the failure of the practice to deliver its intended benefits. Despite the various economic challenges like electricity, security and corruption bedeviling the country leading to exodus of many manufacturing organizations out of Nigeria, one of the major organizations weathering storms and becoming stronger is Dangote Cement. The CSR initiatives of the firm is seen as one of its secret hence the study of the strategy been used. A synthesis of push and pull strategy that is robust and all stakeholder inclusive is adopted by it, pushing its product to the market while also attracting the people to it, hence its success story in the sector.
\end{abstract}

Keywords: Corporate Social Responsibility, Organizations, Pull and Push strategy, Sustainability, Marketing Mix, Situation Response.

DOI: $10.7176 / \mathrm{EJBM} / 11-6-12$

\section{Introduction}

The competitive business environment wherein organizations operates makes adoption of measures for advantageous competition imperative for their survival in the business environment while the globalization of almost every sector of the economy is driving the organizations to synthesizing series of strategies for the purposes of competition and achievement of the organizational goal. More common practice in this area is Corporate Social Responsibility (CSR) initiatives amongst both the local and multinational organizations. CSRs are undertaken for series of benefits its offers in the modern day global economy of which it's primary is the achievement of profitability goal of the organizations, be it in the long or short term basis.

This study, CSR and organization's pull and push strategy in Nigeria economy aims at determining the historical background of CSR in the country, concept mostly utilized in the economy, synthesis of the pull and push strategy with it and immediate contribution of the synthesis to the organizational achievements or performance in the immediate years. This will be done relying solely on secondary data gathered from the annual sustainability reports of some selected organizations across the manufacturing, communication and banking sectors of the Nigerian economy.

\section{Corporate Social Responsibility and Pull and Push Strategy Defined}

CSR is rather not an unknown or new concept in the world of business with numerous authors from previous century to date lending their voices and research works to broaden and shed more light on the concept (Weber, 2008). The numerous authors and researchers on the concept has not excluded it from diverging conception and definition with which each form their perspectives, giving it meaning, thus, there are inarguably as many conceptions and definitions of the concept as its numerous authors (Amaeshi and Adi, 2005). This has made a consensus and globally meeting point to its definition still elusive (Turker, 2009).

Arbitrarily, CSR can be defined as the act of creating public or social goods voluntarily by organizations with a view to gaining more social consideration in their business environment (Drucker, 1954; McWilliams \& Siegel, 2001). The concept can also be conceived as the process of contributing to the socio-economic development of the organization's host environment (Ademosu, 2008; Sharma 2011) also viewed the concept as an act of sustainably treating the organization's stakeholders with respect and dignity that will further enhance the operations of such an organization. The social capital the organization creates in its environment will enhance its reputation and patronage in such an environment (Husted \& Allen, 2006).

The business environment of any organization includes but not limited to its physically environment, it is what Thorne, Mahoney, and Manetti, (2014) defined as the stakeholders of an organization and comprises of, shareholders, employees, customers, host communities and the inanimate physical environment. These stakeholders had initially been long conceived as groups or individuals affected in the process of attaining organizational objectives (Freeman, 1984), while the same author with advent of globalization views stakeholders 
as vital organs to the achievement of organizational objectives (Freeman, 2004), the level of vitality however from the view of Mitchell, Agle \& Wood (1997), differs. In effect, according to Bénabou \& Tirole, (2010), friendly and ethical considerations of an organization should be towards these highlighted groups.

Generally, consensus definition is still elusive to it though with some generally inculcated elements as voluntary, physical and human environmental inclusiveness, philanthropic, healthy competition, ethical considerations, the alignment of the social and economic responsibilities, and the inclusion of values in strategic management policies of organizations. (Aminu, Harashid \& Azlan, 2015).

The push and pull strategy is rather a more frequently used phenomenon in the world of marketing and poverty reduction (USAID, 2014; Kroher, 2015), there had not been known attempt to study its usefulness or application relative to the concept of CSR which is what this study seeks to do. Push and pull strategy is a two throng approach, a synthesis of approaches that can further be broken down into the push and pull strategies.

The push strategy is as the name implies, a marketing strategy employed by business organizations to endear or push their products (goods or services) to the business intermediaries or directly to their customers. Thus, the strategy is purely a promotional strategy to help them achieve their profit objectives. To trade intermediaries, incentives like discounts, gifts, credit sales and bonuses on percentage of sales volume made are offered in a bid for such to push the organization's products to the final consumers either by directly advertising them or merely strategically and preferentially stocking them (Douglas \& Craig, 2012).

The pull strategy is essentially the opposite of the push strategy and it comprises of any move or strategic policy for attracting the consumers of the organization's products directly to the product. In achieving this, demands are created for the products or rather, the products created to meeting some specific needs in the market (Gupta, 2013). More often than not, some organizations inadvertently tries to point the attention of their potential customers to their existing needs (such wants or needs not initially recognized by the end users themselves) that their products will meet or contribute to meeting by triggering the demands for them.

\section{Summary of the Theories of CSR}

As with the definition of the concept that has different perspectives to it so also is the concept having many theories to broaden its understanding (Deegan and Gordon, 1996). Various theories have been developed for better understanding of CSR notable (for their popularity and frequency of usage in the literatures) among which are, the classical, legitimacy, agency, instrumental and stakeholder theories (Idowu, 2018).

The classical theory of CSR stemmed from the Classical Economists and opined that, CSR should remain a voluntary volition of business organizations since it is not directly an income generating activity and as such do not contribute to the profit maximization of businesses (Friedman, 1997). It further argues that, provision of economic gains is what businesses should focus on while Government should be saddled with provision of public goods (Aupperleet et al, 1985). In the words of Idowu (2019), this theory serves as the source of motivation for business organization's passing the buck, and also a bane of the tenet of CSR.

The legitimacy theory borders on the alignment of an organization's with the values, beliefs and norms of its external environments for its acceptance by the environment (Dowling \& Pfeffer, 1975). This theory thus recognizes the fact that, no organization can thrive in the absence of its external environment, while the classical theory recognizes only the internal environment and seeks to satisfy it, this theory sees the external environment as an integral part of any organization in that, it is vital organ to its primary goal attainment and also been affected by the processes that lead to the attainment of the primary goal of profiteering (Mobus, 2005).

The agency theory is rather a different and centric development in the study of CSR, it draws its credibility form the fact that, the management team of any business organization are employees of the business owner, hence its agent and with the moral obligation to only serve the business or profit interest of their employers (Lee, 2008). CSR is thus a secondary concern and could be an outright outcast should the shareholders, employees or managers be mindful only of immediate gain that CSR could not afford (Aupperle et al, 1985).

The instrumental theory is an improvement on the agency theory in that it sees CSR as an instrument for achieving the profit objective of business organizations howbeit not immediate (Idowu \& Ojo, 2016). The theory hinged on the medium and long term advantages like community acceptability (this reduces the costs of maintaining peace), image boosting, customer retention and viral marketing that CSR affords.

Lastly but not the least important is the stakeholders theory of CSR, rather than the classical theory's sole recognition of shareholders and partial recognition of managers as sole vital organs to organizational operation, the stakeholder theory includes the employees, customers i.e. trade intermediaries like suppliers, distributors, consumers, host communities and the environment (Waddock \& Graves, 1997). Thereforewould be successful organizations need to satisfy the various levels of interests of these elements for its profitability sustainability.

\section{Components of CSR}

Though with divergent view, definition, theory and conceptualization, CSR in literatures is greatly skewed towards the bottom three approach, that is, organizations meeting the economic, social and environmental needs in their 
strategies cum operations. Thus, economic gains for the shareholders and customers, social gains for the employees and host communities and environmental gains for the organizations itself and the entirety of its stakeholders since they all relates with the physical environment (Asa, 2007).

The economic responsibilities an organization is expected to pursue to need have the elements of integrity and transparency in its operations, usage of local labour, sourcing materials from ethically certified suppliers, development of hosts communities economy and payment of dues to government. The social responsibilities borders on respect to dignity of human existence, rights of labour, training and proper remuneration of employees, local content and labour development and expertise contribution to community courses while the environmental responsibilities covers all environmentally friendly and sustainable production processes, minimization of negative externalities and replenishment of environmental resources (Carrol,1991; Asa, 2007).

\section{CSR in Traditional Nigeria Setting}

CSR is not a new concept in the Nigerian business world, it is a concept that has been in practice prior to the colonization of the country or the global industrial revolutions, howbeit under different nomenclature (Asa, 2007). Traditionally, local business owners tends to be responsible in their utilization of the common or public goods for their business, for instance, local or primitive launders that uses rivers for washing steers clear of where the communities fetch water for domestic uses, also, they stop their businesses whenever available water is not sufficient for domestic purposes. The practice of good value for money was also promoted making substandard products unpopular, promotional activities like gifts, bonuses, consensus, collectivism, group loyalty and a culture of sharing was popular (Asa, 2007). In the southwest of Nigeria, such acts is coined with the word "Omoluabi", literarily translated as corporate citizen, eniyan laso mi, translated as "humans are my cloak" all underlines the importance of cordial relationship between an organization and its environment (Trompenaars, 1993; Asa, 2007). However, in the modern days, CSR inception is traceable to oil exploration in the Southeastern part of the country as a panacea to the exploitation of these resources by the multinational operating in that region. It should be noted that, their CSR initiatives were rather reactive in nature to the taking up of arms by the youths of those communities who organized themselves into formidable gangs like the Bakkasi Boys (Asa, 2007).

In the Nigerian context, there is paucity of research on CSR while the scanty ones had focused mostly on multinational oil companies in the exploration of oil in Niger Delta (Amaeshi et al 2006; Asa, 2007), posited that, CSR practices in Nigeria is merely a mimicry of the western world while in the words ofIdowu (2014), it is proudly a lip service. CSR in Nigeria is thus majorly driven by foreign multinationals, local and international NonGovernmental Organizations (NGO). Adherence to rule of law to avoid sanctioning and host and international communities' clamoring for sustainable ecosystem, and the concept is purely philanthropic in nature (Loimi, 2002; Asa, 2007).

\section{The Concept of Pull and Push Strategy}

As earlier posited, the pull and push strategy is explained by two theories and hence draws its foundational background from these theories, the theories are, marketing mix and situation response. From the latter, organizations need to strategize such that, a conducive environment or situation is created by its representatives (be it direct employees, suppliers or business intermediaries) to the effect that, values exchange occurs between it and the consumers (Bowman \& Haire, 1975; Rajeshwari, 2006).

In the creation of this ideal conditions to enhance the achievement of value exchange with the organization, pull and push strategies are employed, for instance, the representative either pushes the products to the intending targets or draws such targets to the products. In whatever method employed, motivation remain a primary bait for achieving the expected objective of sales.

The second theory, marketing mix underlines such elements that need be combined together for seamless value exchange between organizations and their business intermediaries or customers, these were initially put at factors, denoted by 4Ps of marketing. These are, product, price, place and promotion (Culliton, 1940). Globalization, modernization and corporate citizenship or ethical awareness in this decade lead to the introduction of additional three elements, the process, people and physical evidence to raise the Ps from 4 to 7 . The important roles played by these added elements in achieving value exchange made their inclusion incontestable. (Eric, 2008).

From the foregoing, it follows that, organizations, to justify their existence must produce products (tangible goods or intangible, services) that meets certain needs in the market. Also, for the acceptance of such products in the market, it will have to comply with the quality regulations of such markets while adequate information about its usage and contradictions must be provided, all these shows element of been corporately responsible.

Following this, the product's value, that is, its cost must be such that is reasonable (safe in the case of some ostentatious products) and affordable for its value by the end users. Various strategies like skimming, leadership and premium are often used by organization depending on their valuation by the customers. Exorbitantly high prices for commonly needed product can raise public outcry and rage against organizations providing such, thus 
denting their social value in their external environment (Fifield, 2007).

The place in this marketing mix explains the availability of such product with minimal cost of accessing to the customers. This implies that, the price they paid for the product as well as other logistics like transportation must be minimal. When products are readily available within the reach of their users, exchange of values are most likely to occur hence the various stakeholders excluding the community and environment can be satisfied. Supply, demand and general price level (price equilibrium) in the perfect market economy relates efficiently to determine exchange of value and perception of the organizations (Fifield, 2007).

The promotion mix underlines any legitimate means of creating awareness for an organization's product. Choice of strategy here must comply with the socio-cultural orientation of the macro-economic environment of such organization for its acceptance. Advertisement (in prints media, like magazines and posters, in social media and mass media like television and radio) must not offend the ethical, moral and religious senses of the people if an organization will be accepted in such an environment (Fifield, 2007).

To enhance social and environmental responsibility of the organization, the fifth $\mathrm{P}$ (process), that is, the efficiency of production strategies relative to the usage of environmental resources was introduced. To be ethical, the production and distribution processes of such products must comply with environmental sustainability and public health safety legislations of the individual markets. Efforts should be made through research and development to come up with more environmental resource efficient strategies while sustainability measures need be put in place by organizations to enhance their social citizenship (Fifield, 2007).

The sixth $\mathrm{P}$ has to do with people. This is because, for any organization to achieve its economic, social and environmental goals, its people (employees) are essential ingredient. The top management where decisions are made to the least on the cadre where such decisions or strategies are often implemented all plays pivotal role in the satisfaction of the other stakeholders. The "people" having a sense of responsibility to their employers (the shareholders) as well as to their external environments (the community and physical environment) for their organization to be seen as been a socially responsible one (Brassington and Pettitt, 2012).

The last (seventh P) but not the least of the mix is physical evidence, this explains the overall immediate environment of where value is to be exchanged and the authenticity of the products to be exchanged. Every buyer wants to buy the right product and in the most conducive environment. In this wise and as part of social responsibility, organizations must endeavor to put in place vividly distinguishing factors not easily and readily replicate-able. This can also be extended to prosecuting business or product copier and intellectual property rights violators of the organization. When buyers are assured of and guided in making informed purchase, a repeat of such will be easier (Fifield, 2007).

\section{Impacts of the Manufacturing Sector on Nigeria's Economy}

The manufacturing sector of any well to do economy globally is according to the world's economic forum of year 2013 is supposed to add value and create the most employment opportunity (Celina, Eze \& Nweke, 2018). However, in Nigeria, a developing nation, the Agricultural sector provides the most employment (more than 70\%) while the oil (upstream) sector provides more than $90 \%$ of foreign exchange for the country, the more reason the sector needs revamping to drive economic growth of the nation (Chete, Adeoti, Adeyinka \& Ogundele, 2016).

The manufacturing sector from 1980 to 1985 witnessed improved contribution from $5.4 \%$ to $10.7 \%$ but declined to $8.1 \%$ by 1990 , and by 1995 it had further declined to $6.7 \%$. This trend had been a continuous process overtime has this contribution had further declined to less than 5\% in recent year (Chete et al., 2016). This is rather a sharp contrast to what is obtained in many other emerging economies like China, Thailand, Brazil, Indonesia and Malaysia where their manufacturing's sectors contribution to real Gross Domestic Products in recent years had been; 30\%, 34\%, 35\%, 28\% and 30\% respectively (Ogbu, 2012).

According to Chete et al., (2016), the nation's manufacturing has not attain the required threshold to driveNigeria's economic growth, this is in spite of the various government's policies and interventions in the sector, the culprit for which is the nation's poor electricity supply (Udah, 2010; Ekpo 2011). This has lead and still leading (since the power supply issue is not yet addressed) many multinationals in the sector to relocate to neighboring countries like Ghana. Notable among which are, Dunlop Nigeria Plc, OK Foods Group, Unilver, Cadbury and PZ (Emmanuel, 2010). Although, some fingered corruption and overdependence on oil revenues to be the bane of manufacturing sectors' growth in Nigeria (Udah, 2010), while Chukwuedo \& Efere (2017) faults lack of investment in human capital development. It is notable to note that, there is scanty research (as at the time of doing this study) undertaken either empirically or otherwise, the contributions of these firm's CSR strategy could have made to their survival and continued stay in the Nigeria's economy, hence, this work seeks to fill this perceived gap.

\subsection{Application of Pull and Pull Strategy in Nigeria's Manufacturing Sector's CSR; Evidence from Dangote Cement}

As earlier posited and reviewed, the pull and push strategy defines the sync of strategies that attracts an organization's products to the customers with those that makes its products attractive to the customers, and CSR 
as a management strategy that seeks to endear an organization to its stakeholders in economic, social and environmental senses.

Dangote Group is one of the household names in Nigeria specifically and Africa in general, this is because the conglomerate has an array of product line that makes a family life in Africa almost incomplete without having used any of its product on a daily basis. Some of these product lines includes foods and beverages (sugar, salt, noodles, flour, rice, wheat, and semolina), building materials (cement, paints, roofing sheets) and more imminently, oil and gas. Apart from a robust financial strength and popularity, the CSR initiative of the organization is believed to also enhance its sustainability in the Nigerian market, this claim will be critically justified subsequently using its cement product line.

The sustainability statement of the organization captures the bottom three duly recognized by almost all the school of thought in CSR, the stakeholders, economy and the environment, and this forms the cardinal upon which its activities are laid as it conducts its businesses to satisfy those three. (Dangote Cement Sustainability, 2017). The 7 pillars of its CSR "the Dangote Way" are, financial, institutional, economic, operational, social, environmental and with a blend of cultural values.

To comply with the Cement Sustainability Initiative of the World Business Council for Sustainable Development (WBCSD), the organization focuses on, Green House Gas (GHG) emission reduction and environmental protection via monthly assessment of its GHG emissions and its reporting at executive forum, responsible usage of its primary raw materials, occupational health and safety and local impact on land and water reserves of its plant's vicinities. The organization is also able to align its sustainability pillars to the United Nations Global Compact of Human rights, labour, environment, and anti-corruption.

\subsubsection{Financial Sustainability}

In its financial sustainability and responsibility, the organization do not only recognize its shareholders but also all the stakeholders as identified in the concept of CSR (Dangote Sustainability, 2017). The organization gives back handsomely to its shareholders that has not been lesser than $\$ 6.00$ per share in thelast five years, its shares currently values at $\$ 265$ in the country's stock exchange market. This is a pull strategy that is endearing more investors to it. To the other stakeholders, the organization contributes to economic advancement through direct and indirect impacts close to $\$ 650$ billion like employment generation, payment of local and national taxes, suppliers and value creations.

\subsubsection{Institutional Sustainability}

The organization, to be adjudged a corporate citizen of the countries of its operations does everything within its powers to comply with government's policies, legislations, international standards and succession planning. The business line for instance employs more than 15,000 Nigerians presently, won the International Standard Organization's ISO award for its succession program and Nigerian Stock Exchange's NSE award of the most compliant listed company all in year 2017. It is seen as a never ending exercise to ensure a smooth transition of the employees from lower to higher cadres, which is needful for uninterrupted profitability. The organization also reports its taxes to various government's agencies in its annual report, this is in compliance with global compact's fourth module of zero tolerance for corruption and bribery.

\subsubsection{Operational Sustainability}

This underlines the firm's responsibility to its employees, communities and the environment wherein it operates. Efficient operational or production processes reduces the cost of production hence, optimizes price mix of the marketing theory. In this regard, resource management, local content development, innovation and management of its supply chain has been the major drivers. Backward integration where byproducts are reused, locally sourcing for raw materials and efficient water management and conservation has been employed.

More than $\$ 15$ b have been invested in its business intermediaries, the distributors were given new trucks with repayment period not lesser than five years and at no interest, this is making its products available to the buyers even in the remotest parts of the country, this is also identified as both a pull and push strategy. The products are pushed to the buyers via efficient distribution channels while the distributors are attracted to the brand because of the interest free loan incentive.

Environmentally, the firm mandated all its suppliers to be fully certified in all the required standards like, quality and environmental management systems, occupational health and safety management system and its supplier's guiding principles. By this initiatives, the firm is pushing itself to the international community as an environmentally responsible organization.

\subsubsection{Cultural Sustainability}

The firm's cultural value is hinged on employee training, mentoring, inclusiveness and giving back to the society. 
In training its employees (one of the stakeholders), the firm establishes academy where seasoned and experienced (including its top management members) offers training for the other employees, it has an annually edited staff handbook that contains all the codes of conducts and values expected of the firm's people (also a pointer to the importance of people mix of the marketing 7p's theory). The firm also seeks to be inclusive by making sure an overall $93.5 \%$ of its employees are indigene of such country while a sizable percentage are locals of the plants. Also, the employees lives with the locals to enhance their integrationinto the live and values of such communities. Also, in its CSR initiatives, the firm dialogues with the community heads and representatives on the areas they need her intervention, this has led to huge acceptance of such initiatives as witnessed by the maintenances and supervisions after completion and handling over that such projects enjoys from the locals.

Through its Dangote Women Network, the firm is able to strike balance in employment relative to gender orientation, through this network as well, the Dangote foundation is able to undergo series of women empowerment programs in their communities. This is unlike what is obtained in the banking sector where most if not all of the CSR efforts are concentrated in highbrow areas in big cities (Idowu, 2014; Idowu \& Ojo, 2016). In year 2017 alone, this network donated a sum of $\$ 20$ million to internally displaced projects IDPs camps in Borno State amongst other relieve items and the company's sisters products.

As part of responsiveness, the women workforce can have full maternity leave as obtainable in federal civil services of each country while they still receive their full salary during this period. This is attracting more female applicants to the firm thus a pull strategy inclined in CSR. In its bid to build customers relationship, the firm in year 2017 started the distribution of 1000 trucks to its customers, 150 mini trucks and 3000 smart (moisture tight and anti-theft), this process had been completed by the middle of the year 2018. This is another strategy in its CSR initiative that pulls more customers to the organization. The firm pushes its products to the customers by providing supports materials like tables, chairs, tarpaulin, parasols, all branded, for more than 25,000 small scale sellers.

\subsubsection{Economic Sustainability}

Economically, the firm contributes to the economic sustainability of the host countries via job creation, return on investment, knowledge transfer, local content development and value addition. The initiatives of the firm in the area of employment borders on youth empowerment in partnership with NG0's, graduate trainee and internship. It sustains close to 28,000 jobs in Nigeria alone for the year 2017 contributing $\$ 72 b$, to household income in Nigeria alone for the year.

\subsubsection{Social Sustainability}

As part of its social sustainability, the firm's initiatives are anchored on community engagement, social investment, training and development and health and safety. With the slogan of zero harm not only to the employees but also to all the physically exposed people to its firm, all the plants are duly certified to be compliant with all safety laws. In order to ensure the safety of her employees, the firm put in place a number of initiatives in the year under reference, this includes monthly safety slogan and meeting, thorough investigation of every incident, and the empowerment of employees at their personal discretion to discontinue any unsafe activities. Also, via its academy, continuous training of the employees is always in place with more than 20,000 employees trained already. In the year 2017 alone, about 600 engineers were trained with more than $90 \%$ reabsorbed into the employment of the firm.

The social investment program of its CSR involves community health projects, and education. The firm beliefs in earning a "social license" so it could operate in all of its communities, this is a very strong tenetof CSR (Waddock \& Graves, 1997). The Gboko, Ibese and Obajana plants had collectively rolled out about $\$ 1 b$ only in year 2017. More specifically, the Gboko plant had spent about $\$ 100 \mathrm{~m}$ on scholarships for indigent students, about $\$ 90 \mathrm{~m}$ on electrification projects, improvement of the transportation network of the community with purchase of 30 tricycles worth $\$ 20 \mathrm{~m}$, provision of 21 boreholes at $\$ 15 \mathrm{~m}$ to improve portable water supply, and $\$ 400,000$ spent (annually) to help raise the vulnerable to food security in the area. These are seen as pull strategy as the initiatives are aimed at attracting people to it products. The people will have moral justification to only buy such products.

The Ibese plant enhances the transportation of its community by constructing concrete roads worth $¥ 3.8 \mathrm{~b}$ so far, and about $\$ 4$ b on repairs of roads. Also, about $\sharp 85 \mathrm{~m}, \sharp 40 \mathrm{~m}, \sharp 22 \mathrm{~m}, \sharp 17 \mathrm{~m}$, and $\sharp 2.5 \mathrm{~m}$ had been spent on portable water provision, construction of classrooms, community health care, scholarships, and vocational trainings for the locals respectively. At its Obajana plant also, the firm had spent about $\$ 590 \mathrm{~m}$ on roads, $\$ 160 \mathrm{~m}$ for development centers, $\mathrm{N} 23 \mathrm{~m}$ on portable water provision, $\$ 22 \mathrm{~m}$, electrification, $\$ 20 \mathrm{~m}$ on legal facilities and about $\$ 20 \mathrm{~m}$ on education. These are also a pull strategy implementation via CSR.

\subsubsection{Environmental Sustainability}

As said earlier, the firm recognizes the important role an all-inclusive CSR implementation plays in achieving social, economic and environmental goals hence its inclusion of the environment as one of the pillars of its CSR. It seeks to greatly minimize the impacts its operations could have especially on its immediate environments hence 
GHG and dust emissions, water management and environmental governance were its core areas of impacts.

Been a huge energy consuming production processes that necessitates huge combustion leading to the emission of $\mathrm{CO}_{2}$ to the environment, measures like usage of natural gas and solar energy were deployed to reduce this emission while it is been duly monitored, reported and discussed at executive meetings. The dust emission of the plants is below the allowable threshold, thanks to deployment of technologies like bag house and electrostatic filters that abates the dusts.

To conserve water, the firm for instance have an earthen pond that collects erosion water which the firm treats and uses for some of its production processes, ensures it does not use any process that pollutes groundwater sources while utilizing water conserving processes as well.

Finally, on environmental sustainability, the group prior to constructing its plants, undertakes baseline analysis of the environment and periodically conducts environmental monitoring exercise in areas as dust discharge, air and sound pollution, and used water discharges. This is to ensure its compliance with various relevant international standard organization's regulations and local environmental standards. The environmental sustainability of the firm is seen purely as a pull strategy to its products (Dangote Sustainability, 2017).

\section{Summary and Categorization of the Strategies}

From the previous findings and discussions, it is noted that, CSR initiative of the firm is highly encompassing in that, all the stakeholders are actively involved and impacted while it addresses the economic, social and environmental triple bottom of the CSR theory. Also, these initiatives could be broadly divided into pull and push strategy, hence the application of the theories of marketing mix andsituational response to create conducive environments that will either attract the people to its product or push the products to the intermediaries and subsequently, to the end users.

In the CSR's initiatives, the identifiable push strategies borders on the marketing mix 4p's, starting from the product that meets the need for bridging housing and infrastructural deficits of the country, quality product that certifies standard organization's legislations and easily handled by the construction workers. The price is competitive while the products are readily available in the market via its robust distribution networks. The promotional mix and elements like advertisements in all the media, packaging, discounting for major distributors as well as easy and efficient means of transportation all positions the product to be vividly seen in the markets. Summarily, the operational sustainability initiatives of the developmental goals of its CSR and the 4Ps of marketing essentially pushes the products to the people.

While the pull strategy were shown by the remaining 3Ps, the process (both the efficient manufacturing and distribution processes), people (remuneration and other benefits) and physical evidence (characteristic packaging, plants and intermediaries environments) draws the people to its product. The remaining sustainability goals of financial (economic rewards pulls more investors to buying its products), institutional, (this pulls more intelligent/committed employees to it), cultural (pulls investors, customers, employees and the communities), economic (pulls the government, investors, business intermediaries, suppliers and employees), social (pulls employees and communities) while the environmental sustainability makes it attractive to both local and international standard organizations, the result been various supply contracts the firm is securing from both the government (at all levels) and private organizations.

\section{Conclusion and Recommendations}

The success stories of the firm in the nation's manufacturing sector cannot possibly come to bare without its robust CSR initiatives that have a good blend of both the push and pull strategies taking its root from the marketing mix and situational analysis theories. Murtala (2017), shows a strong positive correlation between the firm's CSR and profitability for succeeding years. It is thereby recommended that, other organizations both in the industry and outside it should have an inclusive CSR initiatives and efficiently inculcate the push and pull strategy in the designs and implementation of such initiatives. Other researchers with keen interest can in the future include the CSR variable and strategy utilized in experimentally determining their quantitative contributions to the performances of organizations in the economy.

\section{References}

Ademosu, E. A. (2008). Corporate social responsibility: The experience of the Nigeria banking system, available at http://www.acamb.com

Amaeshi, K., \& Adi, B. (2005). Reconstructing the corporate social responsibility construct in Cultish. Nottingham: International Centre for Corporate Social Responsibility.

Amaeshi, K.M., Bongo C. A, Ogbechie, C. \& Amao, O. O (2006). Corporate Social Responsibility (CSR) in Nigeria: Western mimicry or indigenous practices? No. 39-2006 ICCSR Research Paper Series - ISSN 1479- 
5124.

Aminu A. H, Harashid H, \& Azlan, A. (2015). Corporate Social Responsibility: A Review on Definitions, Core Characteristics and Theoretical Perspectives: Mediterranean Journal of Social Sciences MCSERPublishing, Rome-Italy, 6(4)2039-2117.

Asa, H. (2007): Corporate Social Responsibility from a Nigerian perspective (Unpublished) Master Degree thesis of Handelshogskolan Vid Goteborgs Universitet, Germany.

Aupperle, K. E. Caroll, A.B. \& Hatfield, J. B. (1985). An empirical examination of the relationship between corporate social responsibility and profitability, Academy of Management Journal 28 (2), 446-463.

Bénabou, R., \& Tirole, J. (2010). Individual and corporate social responsibility. Economica, 77, 1-19. (Online), Available at: http://dx.doi.org/10.1111/j.1468-0335.2009.00843.x Accessed November 20, 2018.

Bowman, E. H. \& Haire, M. (1975). “A strategic posture toward corporate social responsibility”, California Management Review, 18, 49-58.

Brassington, F. \& Pettitt, S. (2012). Essentials of Marketing. 3rd Ed. Harlow: Pearson.

Carroll, A. (1991). "The Pyramid of Corporate Social Responsibility: Toward the Moral Management of Organizational Stakeholders". Business Horizons, July-August 1991.

Celina, U., Eze, O.M, \& Nweke, A.M: (2018). An analysis of the effect of manufacturing sector on the growth of the Nigerian economy. IOSR Journal of Business and Management 20(4) 34-46

Chete, L. N., Adeoti, J. O., Adeyinka, F. M. \& Ogundele, O. (2016). Industrial development and growth in Nigeria: Lessons and challenges. Nigerian Institute of Social and Economic Research (NISER), Ibadan, Working Paper No. 8

Chukwuedo, S.O \& Ifere, E.O. (2017). Manufacturing Subsector and Economic Growth in Nigeria, British Journal of Economics, Management \& Trade 17(3)1-9

Culliton J. (1940). Marketing Mix Theory. Prentice-Hall International, London.

Dangote Sustainability Report, 2017.

Deegan, C., \& Gordon, B. (1996). A Study of the Environmental Disclosure Practices of Australian Corporations, Accounting and Business Research, 26(3)187-199

Douglas, N.H \& Craig, P.S (2012). Push and Pull Marketing. Journal of service industries, 20(2)95-113.

Dowling, J., \& Pfeffer, J. (1975). Organizational Legitimacy: Societal Values and Organizational Behaviour, Pacific Sociological Review, 18(1)122-136

Drucker, P.F. (1954). The Practice of Management, Collins, New York USA

Ekpo, A.H. (2011). Industrializing a petroleum export-based economy: Nigeria, (1975- 2009). Industrial development: A catalyst for rapid economic growth. In Udoh E, Ogbuagu UR, Essia (eds,) Industrial Development: A Catalyst for Rapid Economic Growth. P.N. Davision Publications, Port Harcourt.

Emmanuel, M. (2010). Nigeria to witness Rujugiros success story; Report of Manufacturer's Association of Nigeria $(M A N)$ AGM by Saturday October 30

Eric, P. (2008). Marketing theories - The of Marketing mix. Available at: https://www.professionalacademy.com/blogs-and-advice/marketing-theories---the-marketing-mix---from-4p-s-to-7-p-s Accessed; 15th November, 2018.

Fifield, P. (2007) - Marketing Strategy, 3rd Edition Butterworth-Heinemann.

Freeman, R. (1984). Strategic Management: A Stakeholder Approach. Boston, MA: Pitman

Freeman, R. (2004). A Stakeholder's Theory of Modern Corporations, Ethical Theory and Business. 7th Edition.

Friedman, M. (1997). "The social responsibility of business is to increase its profits". Corporate ethics andcorporate governance, 173-178

Gupta, N.H (2013). Push and Pull Marketing Culture and Customer Retention. Journal of service industries, 20(2)95-113.

Husted, B. W., \& Allen, D.B. (2006). Corporate social responsibility in the multinational enterprise: strategic and institutional approaches. Journal of International Business Studies, 37(6) 838-849.

Idowu, A. (2014). Corporate Social Responsibility in Nigerian Banking Industry: When will the Lip-Service Games End? Journal of Economics and Sustainable Development. ISSN 2222-1700 (Paper) ISSN 2222-2855 (Online) 5(2)43-50.

Idowu, A. \& Ojo, O. (2016). Factors Necessitating Commercial Banks and Manufacturing Firms' Involvement in Corporate Social Responsibility in Nigeria. Binus Business Review, 7(3), 281-287. http://dx.doi.org/10.21512/bbr.v7i3.1672

Idowu, A. (2019): Passing the Buck, the Bane of Corporate Social Responsibility in Nigeria. World Journal of Innovative Research (WJIR) ISSN: 2454-8236, Volume-6, Issue-1, January 2019 Pages 63-70

Krohemer, H. (2015). Marketing Strategy for Over the Counter (OTC) Health Care Products. Journal of Academic Marketing Science. 28(1)55-66.

Lee, M. P. (2008). A Review of the Theories of Corporate Social Responsibility: Its Evolutionary Path and the Road Ahead, International Journal of Management Reviews, 10, pp. 53-73 
Loimi, A.M. (2002). "Why and how Corporate Social Responsibility, and two case studies". Masters Thesis No 03- 4, School of Economics and Commercial Law, Göteborg University, pp.10-15.

McWilliams, A., \& Siegel, D. (2001). Corporate social responsibility: A theory of the firm perspective. Academy of Management Review, 26(1)117-127.

Mitchell, R.K., Agle, B.R., \& Wood, D.J. (1997). Toward a theory of stakeholder identification and salience: Defining the principle of who and what really counts. Academy of Management Review, 22(4)853-887

Mobus, J.L. (2005). Mandatory environmental disclosure in a legitimacy theory context. Accounting, Auditing and Accountability Journal, 18, 492-517

Murtala, Z. (2017). The Relationship between Corporate Social Responsibility and Profitability: The Case of Dangote Cement Plc. Journal of Finance and Accounting; 5(4)171-176 doi: 10.11648/j.jfa.20170504.18

Ogbu, O. (2012). Toward inclusive growth in Nigeria. Nigerian. Journal of Economic and Social Studies, $43(1) 145$.

Rajeshwari, L. (2006). Right Set of Circumstances Theory of Selling (Online), Available at: https://www.scribd.com/doc/26845291/theories-of-selling

Sharma, N. (2011). CSR practice and reporting in Indian banking sector. International Journal of Advanced Economics and Business Management, 1(2), 58-66.

Thorne, L., Mahoney, L., \& Manetti, G. (2014). Motivations for issuing standalone CSR reports: A survey of Canadian firms, Accounting, Auditing and Accountability Journal, 27(4)686-714.

Trompenaars, F. (1993). "Riding the waves of culture, understanding cultural diversity in business". The Economist Book Ltd, pp. 3, 6-10.

Turker, D. (2009). Measuring corporate social responsibility: A scale development study. Journal of Business Ethics, 85(4), 411-427.

Udah E.B. (2010). Industrial development, electricity crisis and economic performance in Nigeria. European Journal of Economics. Finance and Administrative Sciences. 18:1450-2887.

USAID (2014). Combining Push and Pull Strategies for Greater Scale and Poverty Outreach: Key Takeaways from the 2014 Seep Annual Conference.

Waddock, S. A., \& Graves, S. B. (1997) "The corporate social performance". Strategic management journal, 8(4)303-319.

Weber, M. (2008). The business case for corporate social responsibility: A company level measurement approach for CSR. European Management Journal, 26, 247-261. 